\title{
Foraging behavior of incubating and chick-rearing thick-billed murres Uria lomvia
}

\author{
Motohiro Ito ${ }^{1, *}$, Akinori Takahashi ${ }^{2}$, Nobuo Kokubun ${ }^{2}$, Alexander S. Kitaysky ${ }^{3}$, \\ Yutaka Watanuki ${ }^{1}$
}

\author{
${ }^{1}$ Graduate School of Fisheries Sciences, Hokkaido University, 3-1-1, Minato, Hakodate, Hokkaido 041-8611, Japan \\ ${ }^{2}$ National Institute of Polar Research, 10-3 Midori-cho, Tachikawa, Tokyo 190-8515, Japan \\ ${ }^{3}$ Institute of Arctic Biology, University of Alaska Fairbanks, Irving 311, Fairbanks, Alaska 99503, USA
}

\begin{abstract}
The varying demands associated with egg incubation and chick-rearing are known to have a corresponding effect on the foraging behavior of seabirds. We deployed data loggers on incubating and chick-rearing thick-billed murres Uria lomvia to examine differences in their diving behavior and characteristics of habitats used for foraging. To compare diets of incubating and chickrearing birds we collected their stomach contents using a water offloading technique. We found that incubating birds performed longer foraging trips than chick-rearing birds (incubating: $19.0 \pm 7.2 \mathrm{~h}$; chick-rearing: $9.9 \pm 5.6 \mathrm{~h}$ ). Incubating birds foraged in the offshore stratified water masses (sea surface temperature $[\mathrm{SST}]>9^{\circ} \mathrm{C}$ ) and frequently dived to the depth of the thermocline $(20$ to $50 \mathrm{~m})$. Chick-rearing birds spent more time foraging in the inshore, well-mixed water masses $\left(\mathrm{SST}<8^{\circ} \mathrm{C}\right)$, and at depths $>60 \mathrm{~m}$. Small juvenile walleye pollock Theragra chalcogramma, squid and euphausiids were the dominant prey of incubating and chick-rearing birds. Distributions of these small prey were commonly associated with the thermocline, while larger fish, which parents brought back to feed their chicks, were distributed below the thermocline. Results suggest that incubating murres mainly foraged at shallow depths near the thermocline with higher concentrations of small prey, while chick-rearing murres feed their chicks large prey caught on deep dives while feeding themselves on small prey caught on shallow dives.
\end{abstract}

KEY WORDS: Diving behavior · Brünnich's guillemot $\cdot$ Thermocline $\cdot$ Incubation · Brooding

\section{INTRODUCTION}

Breeding seabirds are central place foragers (Orians \& Pearson 1979) that rely on patchy, ephemeral prey distributed in 3-dimensional space and must return to nesting colonies to relieve their mates of incubation duties or to feed their chicks (Lack 1968, Ashmole 1971). Energy and time allocation differs between incubation and chick-rearing stages of reproduction, which might lead to an adjustment in the foraging behavior of parents (Salamolard \& Weimerskirch 1993, Weimerskirch et al. 1994, Obst et al. 1995, Meyer et al. 1997).

During incubation, parents must meet their energy requirements and relieve their mates of incubation duties. During chick-rearing, they need to obtain sufficient food to sustain both themselves and their chicks, and frequently transport food from foraging grounds to their chicks. There is thus a marked shift in the demands between the incubating and chick-rearing stages of reproduction (Shaffer et al. 2003), and incubating and chick-rearing birds are expected to adopt different foraging tactics in regard to the selection of foraging areas, foraging effort and prey selection (Ydenberg 1994). However, the extent to which seabirds adjust their foraging tactics during the transition from caring for an egg to provisioning a chick is poorly understood (Shaffer et al. 2003). In addition, incubation and chick-rearing usually occur at different time periods, and it is not clear if observed differences 
in foraging behavior of incubation and chick-rearing seabirds reflect temporal changes in prey communities rather than changes due to reproductive stage. Thus behavior of incubation and chick-rearing birds needs to be examined in a single colony during the same time period.

The thick-billed murre Uria lomvia is a pursuit diver that is capable of dives over $100 \mathrm{~m}$ deep (Croll et al. 1992). Males and females share breeding duties equally for the duration of the breeding season, making several foraging trips in a day (Gaston \& Jones 1998). Thick-billed murres are known to dive deeper and spend a greater proportion of time submersed when rearing chicks than when incubating eggs (Benvenuti et al. 2002, Elliott et al. 2008). However, differences in the spatial foraging area and the types of prey items that are coincident with these changes in diving behavior are unclear.

St. George Island, southeastern Bering Sea, holds a large breeding colony of thick-billed murres (approximately 1.1 million pairs, Kitaysky et al. 2000). The marine environment around the island is usually characterized by an inshore ( $<14 \mathrm{~km}$ from the colony), wellmixed water mass with lower sea surface temperatures (SSTs) $\left(<9.0^{\circ} \mathrm{C}\right)$ and offshore $(>14 \mathrm{~km})$, stratified water masses with higher SSTs $\left(>10^{\circ} \mathrm{C}\right)$ (Decker et al. 1995, Decker \& Hunt 1996, Sinclair et al. 2008, Takahashi et al. 2008). In the present study, we used bird-borne data loggers to examine differences in trip duration, use of inshore/offshore water masses and diving behavior between incubating and chick-rearing thick-billed murres breeding on St. George Island during the same time period. We also examined prey of those birds using a water offloading technique.

\section{MATERIALS AND METHODS}

Study area and data-logger deployment. The present study was conducted at the High Bluff colony on the northern side of St. George Island $\left(56^{\circ} 35^{\prime} \mathrm{N}\right.$, $169^{\circ} 35^{\prime} \mathrm{W}$ ) in the Bering Sea during the summer of 2006. Eight birds brooding small chicks and 5 birds incubating eggs were captured from 29 July to 6 August using a $5 \mathrm{~m}$ noose pole. Temperature-depth recording data loggers (diameter: $8 \mathrm{~mm}$, length: $30 \mathrm{~mm}$, weight in air: $2.7 \mathrm{~g}$; Cefas G5, Cefas Technology) were used to record temperature and depth to a resolution of $0.1^{\circ} \mathrm{C}$ and $0.1 \mathrm{~m}$ at $2 \mathrm{~s}$ intervals for up to $8 \mathrm{~d}$. The data loggers were calibrated using a mercury thermometer. Data loggers were attached to the ventral surface of each bird using Tesa ${ }^{\circledR}$ tape (Tremblay et al. 2003, Takahashi et al. 2008). The birds were released within $5 \mathrm{~min}$ and recaptured 2 to $8 \mathrm{~d}$ later. Depth and temperature data were downloaded from the loggers to a computer using custom-written software (G5 Host, Cefas Technology) at the field station.

In murres, negative effects of devices on birds' breeding performance have been previously reported (Wanless et al. 1988, Paredes et al. 2005). In the present study, we also observed a loss of body mass in all individuals fitted with data loggers (incubation: mean $\pm \mathrm{SD}=20.0 \pm 7.1 \mathrm{~g} \mathrm{~d}^{-1}$; chick-rearing: $17.1 \pm 9.2$ $\mathrm{g} \mathrm{d}^{-1}$ ). However, murres usually experience large weight losses during reproduction (Croll et al. 1991), and it was not clear whether the weight loss we observed was due to natural causes or logger deployments. Although negative effects of logger deployments on reproductive performance of murres could not be ruled out, chick mortality among birds fitted with loggers in the present study $(11 \%)$ was markedly lower than previously observed in those fitted with larger devices (33\%, Takahashi et al. 2008), and similar to that of non-instrumented murres breeding on St. George Island in 2006 (15\%, Byrd et al. 2008). Among incubating birds, 1 out of every 6 eggs was lost accidentally at the time of a bird's capture. Takahashi et al. (2008) reported that there were no significant differences in either basal or acute stressinduced levels of corticosterone, a sensitive indicator of stress in seabirds (Kitaysky et al. 2007, in press), between instrumented and non-instrumented murres, suggesting that logger deployment does not have a severe negative effect on their physiology. Finally, the data loggers we deployed were lighter ( $2.7 \mathrm{~g}$ in air) than the $16 \mathrm{~g}$ loggers used by Takahashi et al. (2008), enabling us to minimize potential negative effects of the instrumentation on the birds' behavior.

Diet. The stomach contents of all birds recaptured for logger retrieval were sampled using a water offloading technique (Wilson 1984). Briefly, an elastic tube (diameter $13 \mathrm{~mm}$, length $50 \mathrm{~cm}$ ) was inserted into the bird's proventriculus and $\sim 50$ to $100 \mathrm{ml}$ of lukewarm water was loaded in the stomach. The water and stomach contents were offloaded from the mouth into a bucket by applying gentle pressure to the bird's belly. The procedure was repeated 2 to 3 times until the offloaded water became clear. Stomach samples were then passed through a $0.33 \mathrm{~mm}$ mesh filter and prey items were identified to the lowest taxonomic level using keys for identifying fish otoliths and plankton (Chihara \& Murano 1997). Identifiable prey items were recovered in 4 and 8 of the stomach samples from incubating and chick-rearing birds, respectively.

Analysis of diving profiles. Depth and temperature data recorded by the loggers were analyzed using Igor Pro software (Wave Metrics).

Dive parameters: Dive depth and duration were determined for each dive. Each dive was then divided 
into the following stages: descent (continuous descent following initiation of the dive), bottom time (time between the end of descent and beginning of ascent) and ascent (continuous ascent at the end of the dive). In thick-billed murres, the bottom time of each dive corresponds to foraging time (Mori et al. 2002). Records of $0 \mathrm{~m}$ indicated a surface interval, i.e. the bird was either in flight or resting at the sea surface.

Dive bouts: Thick-billed murres usually performed series of dives that were punctuated by surface intervals. A dive bout was defined as a period of diving activity between 2 long surface intervals (Watanuki et al. 2001). The dive bouts were characterized using the methods of Sibly et al. (1990), with the bout-ending criterion calculated at $255 \mathrm{~s}$. Thus successive dives were grouped into dive bouts when the post-dive surface interval exceeded $255 \mathrm{~s}$.

Diving efficiency: Diving efficiency, defined as the bottom time of dives divided by the sum of the dive time and the post-dive surface interval (intervals $>255$ s were excluded) (Takahashi et al. 2003), was calculated for each dive.

Because the data-loggers were attached to the ventral surface of the birds, they occasionally recorded depths of $<0.5 \mathrm{~m}$ when the birds moved at the sea surface. Consequently, all dive records within $0.5 \mathrm{~m}$ of the ocean surface were excluded from analysis (Watanuki et al. 2001, Takahashi et al. 2008).

Analysis of temperature profiles. SSTs around the island during the year of the study were $<11.5^{\circ} \mathrm{C}$ (Ocean Watch, NASA, http://las.pfeg.noaa.gov/oceanWatch/oceanwatch.php), and air temperatures ranged from 7.0 to $13.0^{\circ} \mathrm{C}$ (National Climate Data Center, NOAA, http://www7.ncdc.noaa.gov/CDO/cdo). Since the temperatures recorded by the data loggers when the birds were at their nesting sites generally exceeded $15.0^{\circ} \mathrm{C}$ (mainly $>20.0^{\circ} \mathrm{C}$, due to heat flux from the skin of the birds), we were able to determine colony departure and arrival time, and thus trip duration (Fig. 1a), from records of temperature (Elliott et al. 2008, Takahashi et al. 2008).

Because the data loggers were attached to the ventral surface of birds, the temperature sensor recorded SST when they were on the sea surface (Tremblay et al. 2003). We therefore used these temperature readings as the SSTs of the waters in which the murres were foraging. SSTs were calculated for each dive bout as the average temperature recorded during post-dive surface intervals after $60 \mathrm{~s}$ from the end of the dive with variations less than $0.3^{\circ} \mathrm{C}$ (Fig. 1b), since the response time of the temperature sensors was relatively slow (28 s for time to reach $66 \%$ of the step from 5 to 30 degrees). Because of the slow response time of the temperature sensor, vertical temperature profiles could not be reliably estimated.

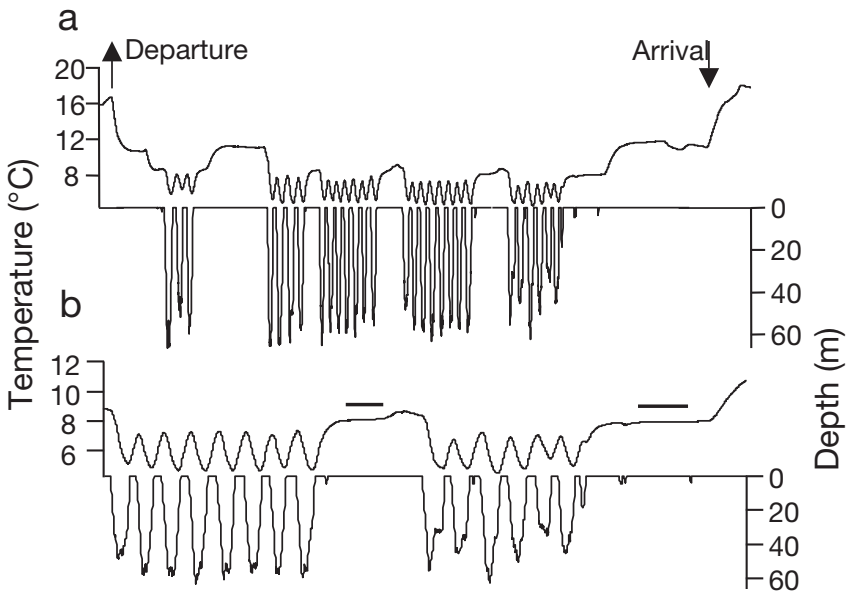

Fig. 1. Uria lomvia. Examples of temperature and depth data recorded by a data logger attached to a chick-rearing thickbilled murre. (a) All records obtained for a single complete foraging trip. Upward and downward arrows indicate a bird's departure and arrival at a breeding site. (b) Expanded records for 20 consecutive dives during the trip (a portion of data presented in [a]). Sea surface temperatures are obtained as the average temperature during the post-dive surface interval and are shown as bold horizontal bars

Statistical analysis. Individual specializations in diving behavior have been previously observed in the thick-billed murre (e.g. Woo et al. 2008, Elliott et al. 2009). This means that birds with longer recording times could have a greater effect on the statistical analysis than birds with relatively shorter recording times. To avoid the likelihood of pseudoreplication, linear mixed models (LMM) were used to compare the foraging trip duration, time spent submerged (per hour during each foraging trip), number of diving bouts per trip per hour, and horizontal utilization of water masses between the 2 reproductive stages (as reflected in SST), between incubating and chick-rearing birds with individual included into the model as random factor.

To compare vertical water mass utilization by incubating and chick-rearing birds, we used 100 randomly selected dives for each bird. Differences in frequency of dive depth distribution (2 m intervals) were examined with Kolmogorov-Smirnov tests. We also compared the percentage of bottom time at depths $>60 \mathrm{~m}$ between incubating and chick-rearing birds using a Mann-Whitney $U$-test. The diving efficiency of incubating and chick-rearing birds was compared using ANCOVA with reproductive stage as a factor and dive depth as a covariate. Diet compositions of incubating and chick-rearing birds were compared by using Fisher's exact test.

All statistical analyses were performed using SPSS (v.11.0) and R (v.2.8.1, R Foundation for Statistical Computing). Data are presented as means \pm SD unless otherwise specified. 


\section{RESULTS}

\section{Trip duration}

A total of 11 and 41 complete foraging trips were obtained from 5 incubating and 8 chick-rearing birds, respectively. All trips comprised several dives of at least $5 \mathrm{~m}$ in depth and $10 \mathrm{~min}$ in total dive time. We excluded 2 trips which recorded only $<3 \mathrm{~min}$ in total dive time and $<5 \mathrm{~m}$ dive depth.

Trip duration ranged between 0.9 and $27.9 \mathrm{~h}$, with incubating birds undertaking longer trips $(19.0 \pm 7.2 \mathrm{~h})$ than chick-rearing birds $\left(9.9 \pm 5.6 \mathrm{~h}\right.$; $\mathrm{LMM}, F_{1,50}=7.1$, $\mathrm{p}<0.05)$.

\section{Water mass utilization shown by SST}

The SSTs encountered by birds ranged from 6.9 to $10.4^{\circ} \mathrm{C}$. Incubating birds mainly foraged in waters with SSTs of 9.0 to $10.4^{\circ} \mathrm{C}$, while chick-rearing birds mainly used waters with SSTs of 9.0 to $9.9^{\circ} \mathrm{C}$ and 7.0 to $7.9^{\circ} \mathrm{C}$ (Fig. 2). The median SST of waters used by incubating birds $\left(9.5^{\circ} \mathrm{C}\right)$ was higher than that of chick-rearing birds $\left(8.5^{\circ} \mathrm{C}\right.$ i LMM, $\left.F_{1,521}=3.2, \mathrm{p}<0.01\right)$ (Fig. 2).

\section{Diving behavior}

A total of 913 and 3393 dives in 178 and 345 dive bouts were recorded for incubating and chick-rearing birds, respectively. The frequency of dives to depths of 1 to $5 \mathrm{~m}$ was very high in both incubating and chickrearing birds, but the percentage of bottom time (corresponding to murre's foraging time, Mori et al. 2002) was low in depths of 1 to $5 \mathrm{~m}$ in both reproductive stages (Fig. 3). Thus 1 to $5 \mathrm{~m}$ dives may not usually be associated with foraging, and dives less than $5 \mathrm{~m}$ were excluded from further analyses. Frequency distributions of dives for each depth range differed significantly between incubating and chick-rearing birds (Kolmogorov-Smirnov test, $D=0.41, \mathrm{p}<0.01$ ) (Fig. 3). In incubating birds, percentage bottom time peaked ( $61 \%$ of total bottom time) between depths of 30 to $50 \mathrm{~m}$ (Fig. 3), while in chick-rearing birds percentage bottom time was more equally distributed among the depth ranges, but included a weak secondary peak observed at depths of 62 to $78 \mathrm{~m}$ (Fig. 3). Chick-rearing birds foraged relatively longer (median $=22 \%, n=8$ birds) at depths $>60 \mathrm{~m}$ than incubating birds (median $=$ $4 \%, \mathrm{n}=8$ birds; Mann-Whitney $U$-test, $U_{1,1}=6.0, \mathrm{p}<$ 0.05).

Diving efficiency was greater when murres dived shallower (Fig. 4), but the difference in those relationships between incubating and chick-rearing birds was mar-

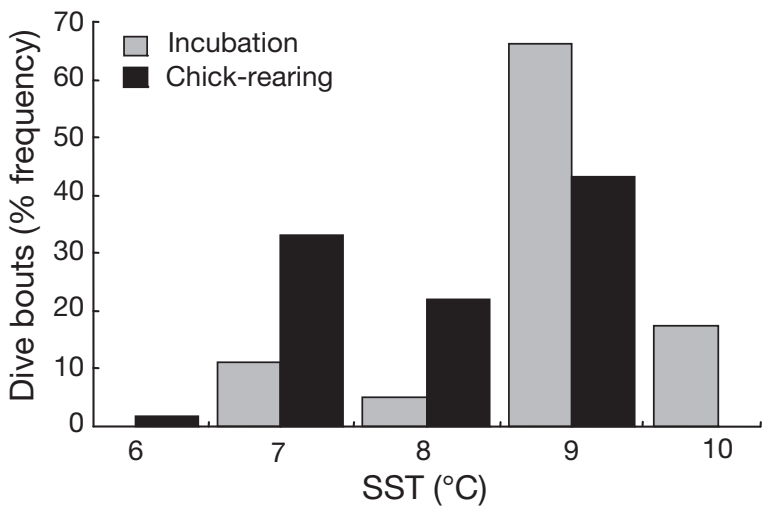

Fig. 2. Uria lomvia. Frequency of dive bouts in relation to the sea surface temperature (SST) in incubating and chick-rearing thick-billed murres. SST data were binned into $1^{\circ} \mathrm{C}$ intervals; whole numbers represent the range for an interval, e.g. 6 represents 6.0 to $6.9^{\circ} \mathrm{C}$

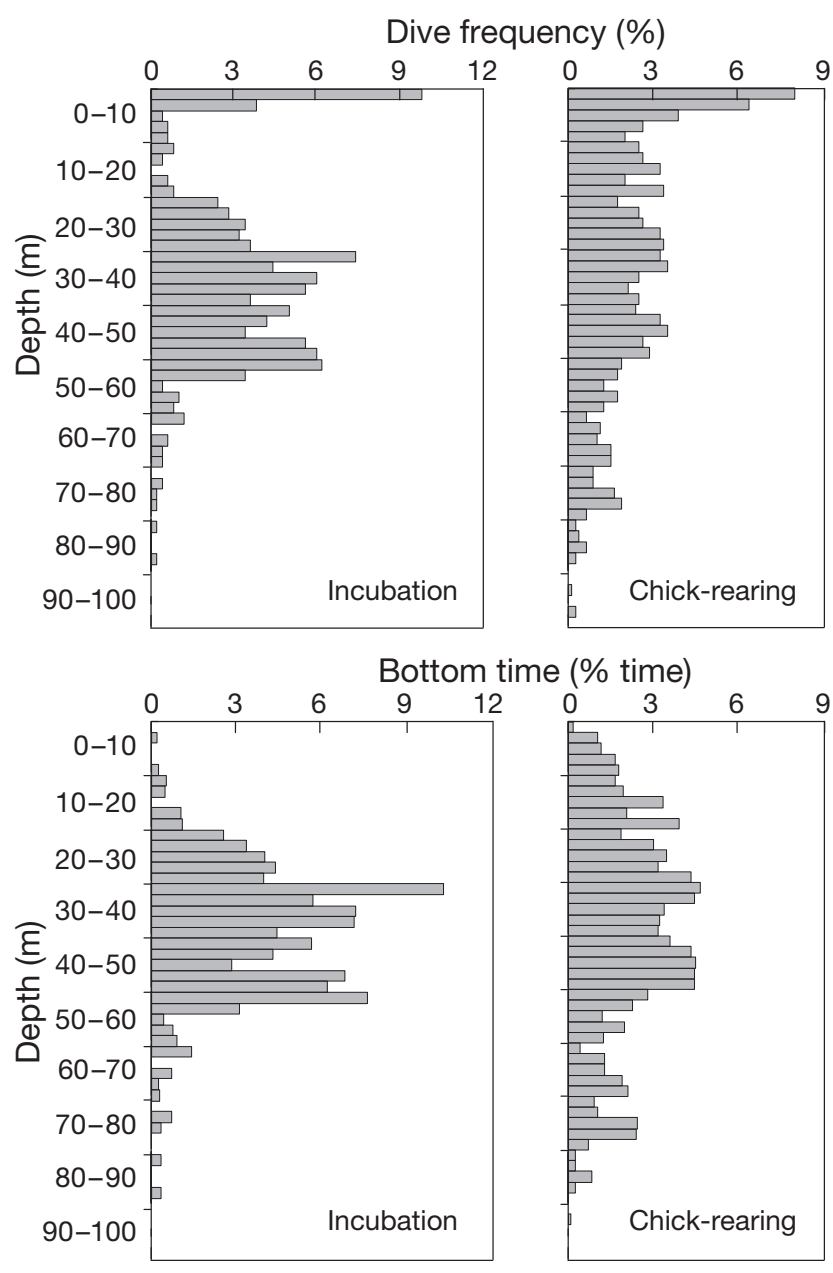

Fig. 3. Uria lomvia. Frequency (\%) distribution of dive depths and proportion of bottom time in relation to dive depth of incubating and chick-rearing thick-billed murres. Depth was binned into $2 \mathrm{~m}$ intervals 


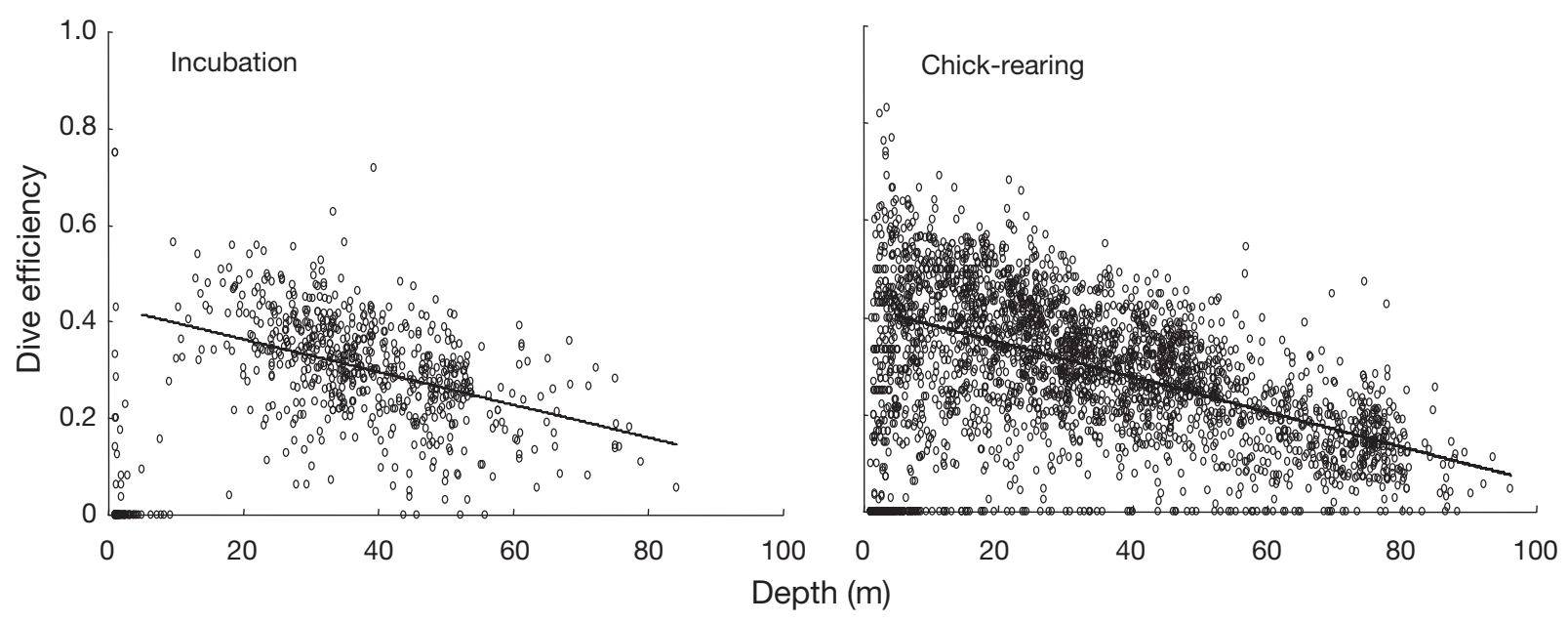

Fig. 4. Uria lomvia. Diving efficiency in relation to dive depth in incubating and chick-rearing thick-billed murres. When dives shallower than $5 \mathrm{~m}$ were excluded from the analysis, the relationships were statistically significant at both reproductive stages (incubation: $y=0.0034 x-0.432, R^{2}=0.25, p<0.01$; chick-rearing: $y=0.0036 x-0.421, R^{2}=0.29, p<0.01$ )

ginal (ANCOVA, $F_{1,2903}=3.6, \mathrm{p}=0.06$ ) (Fig. 4). During foraging trips, chick-rearing birds tended to spend a larger proportion of time diving $(21.2 \pm 11.5 \%)$ compared to incubating birds $(12.5 \pm 5.3 \%)$, though the difference was marginal (LMM, $F_{1,50}=3.8 \mathrm{p}=0.07$ ) (Fig. 5). Mean number of bouts per trip did not differ between incubating $\left(1.3 \pm 0.4\right.$ bouts $\left.\mathrm{h}^{-1}\right)$ and chick-rearing birds $\left(2.4 \pm 6.9\right.$ bouts $\left.\mathrm{h}^{-1} ; \mathrm{LMM}, F_{1,50}=0.3, \mathrm{p}=0.61\right)$.

\section{Diet}

Walleye pollock Theragra chalcogramma were the dominant prey item found in 2 of 4 and 6 of 8 stomachs

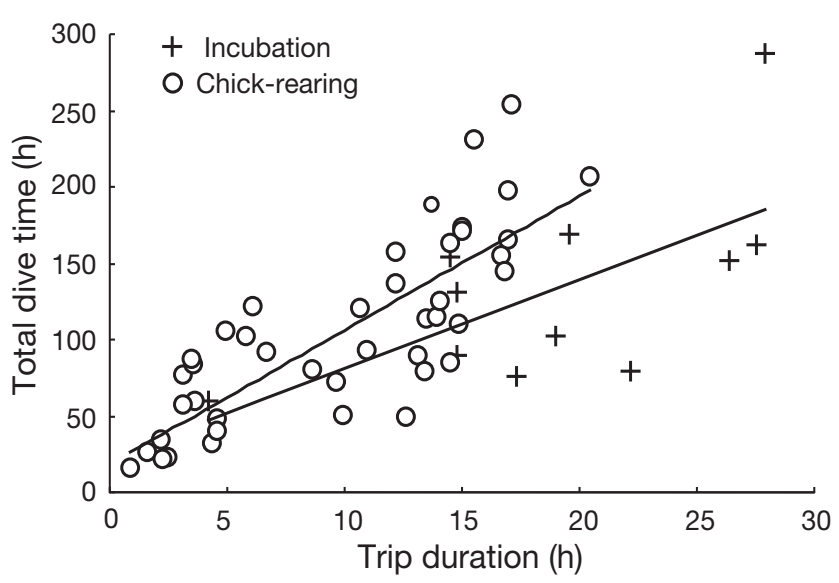

Fig. 5. Uria lomvia. Time spent submerged (i.e. total dive time) in relation to foraging trip duration in incubating and chick-rearing thick-billed murres. The relationships were statistically significant at both reproductive stages (incubation: $y=4.32 x-11.30, R^{2}=0.63, p<0.01$; chick-rearing: $y=$ $\left.2.79 x-26.45, \mathrm{R}^{2}=0.25, \mathrm{p}<0.01\right)$ of incubating and chick-rearing birds, respectively (Table 1). Cephalopods (1 of 4 incubating birds and 2 of 8 chick-rearing birds) and euphausiids (1 of 4 incubating birds and 1 of 8 chick-rearing birds) were also observed in the stomachs of both reproductive stages (Table 1). The frequency of occurrence of prey species in the stomachs of birds did not differ between the reproductive stages (Fisher's exact test, $\mathrm{p}>0.99$ ).

\section{DISCUSSION}

\section{Water masses used by murres for foraging}

Since the observations of foraging behavior in incubating and chick-rearing birds were conducted over the same period, seasonal changes in the marine environment or prey availability could not explain the observed differences.

Table 1. Uria lomvia. Composition of stomach contents in incubating and chick-rearing thick-billed murres. Occurrence is given as frequency (\%) and number $(\mathrm{N})$ of stomachs in which a particular prey item was present. n: number of birds sampled

\begin{tabular}{|lclcc|}
\hline \multirow{2}{*}{ Stage } & \multirow{2}{*}{ P } & Prey & \multicolumn{2}{c|}{ Occurrence } \\
& & & \% & $\mathrm{N}$ \\
\hline Incubation & \multirow{2}{*}{4} & Walleye pollock & 50 & 2 \\
& & Euphausids & 25 & 1 \\
& & Cephalopods & 25 & 1 \\
Chick-rearing & \multirow{2}{*}{8} & Walleye pollock & 75 & 6 \\
& & Euphausiids & 12.5 & 1 \\
& & Cephalopods & 25 & 2 \\
\end{tabular}


Our results corroborate those of previous studies in which it has been demonstrated that breeding common murres Uria aalge and thick-billed murres conduct longer trips during the incubation period than the chick-rearing period (Cairns et al. 1987, Benvenuti et al. 2002). Compared to the thick-billed murres on St. George Island, where incubating and chick-rearing birds spent 19.0 and $9.9 \mathrm{~h}$ on trips, respectively (present study), this species on Hakluyt Island, Greenland, undertook shorter foraging trips (incubating $13.8 \mathrm{~h}$, chick-rearing $8.0 \mathrm{~h}$ ) (Benvenuti et al. 2002). Because of density-dependent competition for the food resources near the colony, seabirds that breed at a larger breeding colony may conduct longer foraging trips to distant foraging areas than those at smaller ones (northern gannet Morus bassanus, Lewis et al. 2001; common murre, Davoren \& Montevecchi 2003). The colony size of thick-billed muures on St. George Island (approximately 1.1 million pairs) is larger than that in Hakluyt Island (26000 pairs, Benvenuti et al. 2002), which might explain why murres made longer foraging trips in the present study than in Benvenuti et al. (2002).

Ship-based surveys around St. George Island have shown that the transition from the well-mixed inshore water to stratified offshore waters occurs 10 to $20 \mathrm{~km}$ from the island and that these disparate water masses form a front (Decker \& Hunt 1996, Sullivan et al. 2008). In 2006, the observed SSTs of 6.0 to $8.0^{\circ} \mathrm{C}$ corresponded with well-mixed inshore waters, while SSTs of 8.0 to $9.0^{\circ} \mathrm{C}$ and 9.0 to $11.0^{\circ} \mathrm{C}$ corresponded with stratified regions further offshore (N. Kokubun et al. unpubl. data). Incubating murres undertook longer trips and foraged in waters with higher SSTs (9.0 to $10.4^{\circ} \mathrm{C}$ ), indicating that they foraged in stratified offshore waters more than $20 \mathrm{~km}$ away from the island. Chick-rearing murres foraged in waters with lower SSTs $\left(6.0\right.$ to $\left.8.0^{\circ} \mathrm{C}\right)$, indicating that they foraged in the well-mixed waters in the vicinity of the island. The longer foraging trips undertaken by incubating murres probably occurred as a result of the increased time required to reach the stratified waters farther offshore.

Another possible reason for the longer foraging trips undertaken by incubating murres might be related to the high energy costs of flight in murres and loss of time that otherwise could be allocated to foraging. Specifically, commuting long distances between foraging locations and the colony would incur high energy and time costs if the incubating birds were to commute as frequently as they do during chickrearing (Houston et al. 1996). Thus incubating murres, which did not need to return to their nests frequently to feed their chicks, spent a longer time foraging at sea.

\section{Prey distribution and dive depth}

Frequency distributions of dives for each depth range differed significantly between incubating and chick-rearing murres (Fig. 3). Chick-rearing birds spent $\sim 5$ times longer bottom time at depths $>60 \mathrm{~m}$ than incubating birds. Incubating birds mainly foraged at depths of 30 to $50 \mathrm{~m}$, while chick-rearing birds foraged at a variety of depths, including greater effort at depths $>60 \mathrm{~m}$ than incubating birds.

The vertical depth distribution of prey may affect predator dive depth. Thick-billed murres in the present study mainly fed on juvenile walleye pollock and occasionally on euphasiids and squid. It is important to note that the diet information based on stomach contents data can be biased due to rapid digestion of soft-bodied prey (e.g. crustaceans, Bradstreet 1980) and extended retention of hard body parts (e.g. squid beaks, Wilson et al. 1985). Retention times of stomach contents in the black guillemot Cepphus grylle and Atlantic puffin Fratercula arctica were 2.7 to $3.8 \mathrm{~h}$ (Hilton et al. 2000), which is shorter than the trip duration of the murres in the present study. Consequently, the proportion of soft-bodied prey such as euphausiids in the diets of the murres in the present study might have been underestimated, and it is possible that adult breeding murres may depend on euphausiids more heavily than we estimated.

The distribution of juvenile walleye pollock is usually associated with the thermocline at around $40 \mathrm{~m}$ in the Bearing Sea (Brodeur 1998, Schabetsberger et al. 2000, 2003, Kokubun et al. 2008). High densities of euphausiids occur epipelagically on the stratified side of the frontal region in the vicinity of St. George Island (Hunt et al. 1996a, Schabetsberger et al. 2000). In 2006, thermoclines developed between 20 and $50 \mathrm{~m}$ in the stratified waters offshore (N. Kokubun et al. unpubl. data). Observations of incubating murres diving repeatedly to depths of 30 to $50 \mathrm{~m}$ (Fig. 3) suggest that birds were foraging near the thermocline where juvenile pollock and euphausiids are typically concentrated.

Previous studies have showed that thick-billed murre parents deliver larger fish such as capeline Mallotus villosus, arctic cod Boreogadus saida, blennies Blennioidea or sculpin Cottidae to their chicks, and they themselves feed on a variety of smaller prey (i.e. amphipods and euphausiids, Hunt et al. 1981, Gaston $\&$ Hipfner 2000). Similar observations were made for common murres on the Isle of May, North Sea (Wilson et al. 2004). At St. George Island, large fish (i.e. $>80 \mathrm{~mm}$ age- 0 and age-1 pollock) have been reported as the main prey items in chick diets in some years (Hunt et al. 1996b, Sinclair et al. 2008, M. Ito et al. unpubl. data), and these fishes usually occur below the thermocline (Winter \& Swartzman 2006). In addition, 
other prey items fed to chicks in 2006 included large inshore benthic fish such as flatfish, sculpin and prickleback (N. Kokubun et al. unpubl. data). Thus, to feed their chicks, birds probably targeted these larger prey during deep dives. Chick-rearing murres also dived at shallower depths near the thermocline (20 to $50 \mathrm{~m}$ ), probably to catch smaller prey items (small juvenile pollock and euphausiids) for their own consumption.

\section{Physiological constraints and foraging tactics}

Murres maintain their vertical speed within a narrow range during descent and ascent (1.2 to $1.8 \mathrm{~m} \mathrm{~s}^{-1}$, Lovvorn et al. 2004, Watanuki et al. 2003, 2006). Consequently, for a given dive duration, the dive depth determines the bottom time. The dive efficiency of thick-billed murres in the present study was greater for shallow dives because of the shorter post-dive surface interval and shorter time required for descent and ascent (Fig. 4). The ANCOVA results for the differences in dive efficiency at a given depth between incubating and chick-rearing birds were marginally significant. However, the differences in effect size (slope and intercept) between incubating and chick-rearing birds was small (Fig. 4), even if the sample size was sufficiently large. Thus we suggest that there is no biological significance to the difference in those relationships between incubating and chick-rearing birds. This indicates physiological constraints (oxygen stores accumulated during post-dive surface interval, for example), so that the birds could not adjust the bottom time according to their reproductive stages. Under these physiological constraints, chick-rearing murres presumably conducted deep dives, which maximized chick-provisioning rates (Wilson et al. 2004) but reduced diving efficiency (Fig. 4).

The difference in the proportion of dive time per trip between the reproductive stages was marginally significant, which might be caused by small sample size in the LMM analysis $(\mathrm{n}=52$; see Fig. 5$)$. The mean proportion of dive time per trip in chick-rearing birds was about 2 times larger than that in incubating birds. The longer dive times during chick-rearing possibly reflect an increase in the foraging effort required to capture large fishes for chicks at deeper depth, resulting in lower diving efficiency, and to compensate, a higher time cost associated with the commute between foraging locations and the colony.

Younger thick-billed murres lay eggs later than older murres (de Forest \& Gaston 1996), which means that the incubating birds in the present study were likely to be younger than the chick-rearing birds. Although we were unable to control for age effects in the present study, foraging ability and dive efficiency of thick-billed murres have been shown to be independent of age (K. H. Elliott \& A. J. Gaston unpubl. data). Furthermore, our results are consistent with those of other studies. For example, incubating birds undertook longer foraging trips and dived shallower than chickrearing birds observed over the same period in both thick-billed murres (Benvenuti et al. 2002) and king penguins Aptenodytes patagonicus (Charrassin et al. 1998). Numerous studies have shown that incubating seabirds have larger foraging ranges (chinstrap penguin Pygoscelis antarctica, Ichii et al. 2007), dive shallower (black-vented shearwater Puffinus opisthomelas, Keitt et al. 2000) or forage more efficiently (wandering albatross Diomedea exulans, Shaffer et al. 2003) than chick-rearing birds, although the effects of season were not controlled for in those studies. Thus, thick-billed murres, like other seabirds, adopt a flexible foraging strategy, allowing them to alter their foraging site, dive depth and foraging effort to meet changing energy and time demands during a transition from the incubation to chick-rearing stages of reproduction.

Acknowledgements. We are grateful to K. Holser, V. Byrd, R. Papish and the team members of 'Cottage C' on St. George Island for their invaluable logistical support. This work was supported by a 21st Century COE program (Neo-Science of Natural History, lead by H. Okada), and partially supported by the Japan Society for the Promotion of Sciences Research Fellowship for Young Scientists to N.K. and A.T., and North Pacific Research Board grants to A.S.K. This study was conducted under required federal and state permits, and under University of Alaska IACUC approval.

\section{LITERATURE CITED}

Ashmole NP (1971) Sea bird ecology and the marine environment. In: Farner D, King JR (eds) Avian biology, Vol I. Academic Press, New York, p 223-286

Benvenuti S, Dall'Antonia L, Falk K (2002) Diving behaviour differs between incubating and brooding Brünnich's guillemots, Uria lomvia. Polar Biol 25:474-478

Bradstreet MSW (1980) Thick-billed murres and black guillemots in the Barrow Strait area, N.W.T., during spring: diets and food availability along ice edges. Can J Zool 58: $2120-2140$

Brodeur RD (1998) In situ observations of the association between juvenile fishes and scyphomedusae in the Bering Sea. Mar Ecol Prog Ser 163:11-20

Byrd GV, Sydeman WJ, Renner HM, Minobe S (2008) Responses of piscivorous seabirds at the Pribilof Islands to ocean climate. Deep-Sea Res II 55:1856-1867

Carins DK, Bredin KA, Montevecchi WA (1987) Activity budgets and foraging ranges of breeding common murres. Auk 104:218-224

> Charrassin JB, Bost CA, Pütz K, Lage J, Dahier T, Zorn T, Le Maho Y (1998) Foraging strategies of incubating and brooding king penguins Aptenodytes patagonicus. Oecologia 114:194-201

Chihara M, Murano M (1997) An illustrated guide to marine plankton in Japan. Tokai University Press, Tokyo 
Croll DA, Gaston AJ, Noble DG (1991) Adaptive loss of mass in thick-billed murres. Condor 93:496-502

Croll DA, Gaston AJ, Burger AE, Konnoff D (1992) Foraging behaviour and physiological adaptation for diving in thick-billed murres. Ecology 73:344-356

> Davoren GK, Montevecchi WA (2003) Consequences of foraging trip duration on provisioning behaviour and fledging condition of common murres. J Avian Biol 34:44-53

de Forest LN, Gaston AJ (1996) The effect of age on timing of breeding and reproductive success in the thick-billed murre. Ecology 77:1501-1511

- Decker MB, Hunt GL Jr (1996) Foraging by murres (Uria spp.) at tidal fronts surrounding the Pribilof Islands, Alaska, USA. Mar Ecol Prog Ser 139:1-10

Decker MB, Hunt GL Jr, Byrd GV (1995) The relationships among sea-surface temperature, the abundance of juvenile walleye pollock (Theragra chalcogramma), and the reproductive performance and diets of seabirds at the Pribilof Islands, southeastern Bering Sea. Publ Spec Can Sci Halieut Aquat 121:425-437

Elliott KH, Jacobs SR, Ringrose J, Gaston AJ, Davoren GK (2008) Is mass loss in Brünnich's guillemots Uria lomvia an adaptation for improved flight performance or improved dive performance? J Avian Biol 39:619-628

Elliott KH, Woo J, Gaston AJ (2009) Specialization in murres: the story of eight specialists. Waterbirds 32:491-506

Gaston AJ, Hipfner JM (2000) Thick-billed murre (Uria lomvia). In: Poole A, Gill F (eds) The birds of North America, No. 497. The Birds of North America, Philadelphia, PA

Gaston AJ, Jones IL (1998) The auks. Oxford University Press, New York

- Hilton GM, Furness W, Houston DC (2000) A comparative study of digestion in North Atlantic seabirds. J Avian Biol 31:36-46

Houston AI, Thompson WA, Gaston AJ (1996) The use of time and energy budget model of a parent bird to investigate limits to fledging mass in the thick-billed murre. Funct Ecol 10:432-439

Hunt GL Jr, Burgeson B, Sanger GA (1981) Feeding ecology of seabirds of the eastern Bering Sea. In: Hood DW, Calder JA (eds) The eastern Bering Sea shelf: oceanography and resources, Vol 2. University of Washington Press, Seattle, WA, p 629-647

Hunt GL Jr, Coyle KO, Hoffman S, Decker MB, Flint EN (1996a) Foraging ecology of short-tailed shearwaters near the Pribilof Islands, Bering Sea. Mar Ecol Prog Ser 141: $1-11$

Hunt GL Jr, Kitaysky AS, Decker MB, Dragoo DE, Springer AM (1996b) Changes in the distribution and size of juvenile walleye pollock as indicated by seabird diets at the Pribilof Islands, and by bottom trawl surveys in the eastern Bering Sea. In: Brodeur RD, Livingston PA, Loughlin TR, Hollowed AG (eds) Ecology of juvenile walleye pollock, Theragra chalcogramma. NOAA Tech Rep NMFS 126: 133-147

Ichii T, Bengtson JL, Boveng PL, Takao Y and others (2007) Provisioning strategies of Antarctic fur seals and chinstrap penguins produce different responses to distribution of common prey and habitat. Mar Ecol Prog Ser 344:277-297

Keitt BS, Croll DA, Tershy BR (2000) Dive depth and diet of the black-vented shearwater (Puffinus opisthomelas). Auk 117:507-510

Kitaysky AS, Hunt GL Jr, Flint EN, Rubega MA, Decker MB (2000) Resource allocation in breeding seabirds: responses to fluctuations in their food supply. Mar Ecol Prog Ser 206: 283-296

Kitaysky AS, Piatt JF, Wingfield JC (2007) Stress hormones link food availability and population processes in seabirds Mar Ecol Prog Ser 352:245-258

Kitaysky AS, Piatt JF, Hatch SA, Kitaiskaia EV, BenowitzFredericks ZM, Shultz MT, Wingfield JC (in press) Food availability and population processes: severity of nutritional stress during reproduction predicts survival of long-lived seabirds. Funct Ecol doi:10.1111/j.1365-2435. 2009.01679.x

Kokubun N, Iida K, Mukai T (2008) Distribution of murres (Uria spp.) and their prey south of St. George Island in the southeastern Bering Sea during the summers of 2003-05. Deep-Sea Res II 55:1827-1836

Lack D (1968) Ecological adaptations for breeding in birds. Methuen, London

Lewis S, Sherratt TN, Hamer KC, Wanless S (2001) Evidence of intra-specific competition for food in a pelagic seabird. Nature 412:816-819

Lovvorn JR, Watanuki Y, Kato A, Naito Y, Liggins GA (2004) Stroke patterns and regulation of swim speed and energy cost in free-ranging Brünnich's guillemots. J Exp Biol 207: 4679-4695

Meyer WR, Bengston JL, Jansen JK, Russell RW (1997) Relationships between brood size and parental provisioning performance in chinstrap penguins during the chick guard phase. Polar Biol 17:228-234

Mori Y, Takahashi A, Mehlum F, Watanuki Y (2002) An application of optimal diving models to diving behaviour of Brünnich's guillemots. Anim Behav 64:739-745

Obst BS, Russell RW, Hunt GL Jr, Eppley ZA, Harrison NM (1995) Foraging radii and energetics of least auklets (Aethia pusilla) breeding on three Bering Sea islands. Physiol Zool 68:647-672

Orians GH, Pearson NE (1979) On the theory of central place foraging. In: Horn DJ, Stairs GR, Mitchell R (eds) Analysis of ecological systems. Ohio State University Press, Columbus, OH, p 155-177

Paredes R, Jones IL, Boness DJ (2005) Reduced parental care, compensatory behaviour and reproductive costs of thickbilled murres equipped with data loggers. Anim Behav 69:197-208

Salamolard M, Weimerskirch H (1993) Relationship between foraging effort and energy requirement throughout the breeding season in the wandering albatross. Funct Ecol 7:643-652

Schabetsberger R, Brodeur RD, Ciannelli L, Napp JM, Swartzman GL (2000) Diel vertical migration and interaction of zooplankton and juvenile walleye pollock (Theragra chalcogramma) at a frontal region near the Pribilof Islands, Bering Sea. ICES J Mar Sci 57:1283-1295

Schabetsberger R, Sztatecsny M, Drozdowski G, Brodeur RD and others (2003) Size-dependent, spatial, and temporal variability of juvenile walleye pollock (Theragra chalcogramma) feeding at a structural front in the Southeast Bering Sea. PSZN I: Mar Ecol 24:141-164

Shaffer SA, Costa DP, Weimerskirch H (2003) Foraging effort in relation to the constraints of reproduction in freeranging albatrosses. Funct Ecol 17:66-74

Sibly RM, Nott HM, Fletcher DJ (1990) Splitting behaviour into bouts. Anim Behav 39:63-69

Sinclair EH, Vlietstra LS, Johnson DS, Zeppelin TK and others (2008) Patterns in prey use among fur seals and birds in the Pribilof Islands. Deep-Sea Res II 55:1897-1918

Sullivan ME, Kachel NB, Mordy CW, Stabeno PJ (2008) The Pribilof Islands: temperature, salinity and nitrate during summer 2004. Deep-Sea Res II 55:1729-1737

> Takahashi A, Dunn MJ, Trathan PN, Sato K, Naito Y, Croxall JP (2003) Foraging strategies of chinstrap penguins at 
Signy Island, Antarctica: importance of benthic feeding on Antarctic krill. Mar Ecol Prog Ser 250:279-289

Takahashi A, Matsumoto K, Hunt GL, Shultz MT and others (2008) Thick-billed murres use different diving behaviors in mixed and stratified waters. Deep-Sea Res II 55: 1837-1845

Tremblay Y, Cherel Y, Oremus M, Tveraa T, Chastel O (2003) Unconventional ventral attachment of time-depth recorders as a new method for investigating time budget and diving behaviour of seabirds. J Exp Biol 206:1929-1940

Wanless S, Harris MP, Morris JA (1988) The effect of radio transmitters on the behavior of common murres and razorbills during chick rearing. Condor 90:816-823

- Watanuki Y, Mehlum F, Takahashi A (2001) Water temperature sampling by Brünnich's guillemots with bird-borne data loggers. J Avian Biol 32:189-193

Watanuki Y, Niizuma Y, Gabrielsen GW, Sato K, Naito Y (2003) Stroke and glide of wing-propelled divers: deep diving seabirds adjust surge frequency to buoyancy change with depth. Proc R Soc Lond B 270:483-488

Watanuki Y, Wanless S, Harris M, Lovvorn JR, Miyazaki M, Tanaka H, Sato K (2006) Swim speeds and stroke patterns in wing-propelled divers: a comparison among alcids and

Submitted: August 5, 2009; Accepted: February 6, 2010 a penguin. J Exp Biol 209:1217-1230

> Weimerskirch H, Chastel O, Ackermann L, Chaurand T, Cuenot-Chaillet F, Hindermeyer X, Judas J (1994) Alternate long and short foraging trips in pelagic seabird parents. Anim Behav 47:472-476

Wilson RP (1984) An improved stomach pump for penguins and other seabirds. J Field Ornithol 55:109-112

Wilson RP, La Cock GD, Wilson MP, Mollagee F (1985) Differential digestion of fish and squid in jackass penguins, Spheniscus demersus. Ornis Scand 16:77-79

Wilson LJ, Daunt F, Wanless S (2004) Self-feeding and chick provisioning diet differ in the common guillemot Uria aalge. Ardea 92:197-208

Winter AG, Swartzman GL (2006) Interannual changes in distribution of age- 0 walleye pollock near the Pribilof Islands, Alaska, with reference to the prediction of pollock yearclass strength. ICES J Mar Sci 63:1118-1135

- Woo KJ, Elliott KH, Davidson M, Gaston AJ, Davoren GK (2008) Individual specialization in diet by a generalist marine predator reflects specialization in foraging behaviour. J Anim Ecol 77:1082-1091

Ydenberg RC (1994) The behavioral ecology of provisioning in birds. Ecoscience 1:1-14

Proofs received from author(s): March 1, 2010 